\title{
ЭКОНОМИЧЕСКАЯ ДОСТУПНОСТЬ КАК ОСНОВА БАЛАНСА ИНТЕРЕСОВ СУБЪЕКТОВ ПРИРОДОПОЛЬЗОВАНИЯ В РЫНОЧНЫХ УСЛОВИЯХ
}

\author{
(c) 2020 Майоров Игорь Геннадьевич \\ кандидат экономических наук, доцент кафедры бизнес технологий и управления, \\ МИРЭА - Российский технологический университет, Москва, Россия
}

\section{(c) 2020 Третьяков Александр Георгиевич}

кандидат экономических наук, доцент кафедры экономики и менеджмента, Омский региональный институт, Омск, Россия

В данной статье рассмотрены основные группы субъектов природопользования и представлен анализ их интересов в рыночных условиях. На примере сферы лесных отношений изучена совокупность противоречий, возникающих между субъектами природопользования. Разработаны предложения по использованию экономической доступности природных ресурсов, как основы обеспечения баланса интересов субъектов в сфере природопользования и инструмента планирования.

Ключевые слова: природопользование, экономическая доступность, природные ресурсы, лесной сектор, рента, интересы, противоречия.

Использование и воспроизводство природных ресурсов обеспечивает одну из главных составляющих развития общественного производства. Любое производство основано на потреблении тех или иных ресурсов, которые в конечном итоге при своем формировании задействуют определенные элементы природных ресурсов. Под природными ресурсами мы понимаем природные компоненты, которые могут быть использованы или используются как предметы потребления (нефть, газ, уголь) или как средства производства (сельскохозяйственные угодья). Экономические отношения, связанные с присвоением, использованием, воспроизводством и охраной природных ресурсов и экологических благ, характеризуются такой экономической категорией как природопользование [4].

Высокая значимость природных ресурсов для человечества в целом, предопределяет важность рационального управления ими, которое базируется на существующих взаимоотношениях между субъектами природопользования. Целью данной статьи является осуществление анализа взаимодействия субъектов природопользования в области экономических отношений и разработка предложений по оптимизации данного взаимодействия на базе использования такой экономической категории как доступность природных ресурсов. Особенно актуальна данная проблема для России, обладающей богатейшими запасами природных ресурсов, и экономика которой в значительной степени за- висит от их эффективной эксплуатации. К таким ресурсам в первую очередь можно отнести ресурсы, имеющие хозяйственное назначение, такие как лесные ресурсы, сельско-хозяйственные угодья, минерально-сырьевые ресурсы, рыбопромысловые и охотничье-промысловые ресурсы и водные ресурсы. Данные ресурсы характеризуются наличием затрат на их освоение или добычу, а также они обычно являются первоначальным звеном в цепочке создания различных продуктов (услуг) на их основе [5].

Рассматривая отношения в области природопользования можно выделить три основных группы субъектов, которые взаимодействуют между собой в этой сфере: бизнес-структуры (предприниматели), государство и население страны (общество). «Экономические отношения каждого данного общества проявляются прежде всего как интересы» как писал Ф. Энгельс [10], следовательно исходя из них следует осуществлять анализ экономического взаимодействия этих субъектов.

Каждый из субъектов природопользования имеет собственные интересы, которые должны быть сбалансированы с интересами других участников взаимоотношений. Данные интересы могут быть выражены следующими положениями:

- бизнес-структуры (предприниматели), стремятся обеспечить себе максимизацию дохода от эксплуатации природных ресурсов, при этом часто на практике данная цель ими рас- 
сматривается в краткосрочной перспективе, без учета тех или иных последствий, которые могут возникнуть в далеком будущем,

- государство, как собственник, имеет двойственные интересы, с одной стороны, оно заинтересовано в получении дохода от использования ресурса, который принимает форму платы (налога) за ресурс, а с другой стороны, оно заинтересовано в поддержании ресурсного потенциала страны, а также в сохранении и в приумножении выполнения ресурсами различных социальных и экологических функций, которые наиболее часто выполняют воспроизводимые природные ресурсы, например, лесные ресурсы.

- общество (население страны), заинтересовано в сохранении природных ресурсов как существенного условия отдыха и здоровья, как основы жизни будущих поколений. В общей форме данное положение закреплено в ст. 9 Конституции РФ, согласно которой природные ресурсы «используются и охраняются в Российской Федерации как основа жизни и деятельности народов, проживающих на соответствующей территории» [1]. Также в ст. 36 Конституции РФ предусматривается, что пользование природных ресурсов собственником не должно наносить ущерб окружающей среде и нарушать права и законные интересы других лиц.

Интересы субъектов взаимоотношений в области природопользования выражаются различными структурами, в число которых входят:

- бизнес-структуры (предприниматели) огромное число коммерческих структур, работающих в области природопользования начиная от вертикально-интегрированных компаний федерального уровня и до отдельных индивидуальных предпринимателей, а также различные объединения производителей;

- государство - федеральные и региональные органы государственной власти;

- общество (население страны) - представительные органы власти, различные общественные организации, включая общественные природоохранные организации.

Кроме основных групп субъектов природопользования можно выделить муниципальные органы власти (например, выполняющие функции предоставления под вырубку леса для населения при заготовке дров), а также и отдельных граждан, которые занимаются природопользованием не с целью получения прибыли, а для удовлетворения собственных потребностей (сбор грибов и дикорастущих ягод для собственных нужд, рыбалка, заготовка дров, выращивание овощей и фруктов на дачном участке и т.д.). Состав участников отношений в различных сферах природопользования регламентируется соответствующими статьями Кодексов (например, лесные отношения - ст. 4 ЛК РФ, земельные отношения - ст. 6 ЗК РФ, водные отношения - ст. 7 ВК РФ). Данный состав идентичен и включает в себя:

- Российскую Федерацию,

- субъекты Российской Федерации,

- муниципальные образования,

- граждан (физические лица - в ВК РФ),

- юридические лица.

Правила использования природных ресурсов, права и обязанности природопользователей закреплены в экологическом законодательстве [7]. В качестве основных документов регламентирующих права и обязанности природопользователей (собственников) можно выделить:

ст. 38 Водного Кодекса РФ - права и обязанности собственников водных объектов,

ст. 40 Земельного Кодекса РФ - права собственников земельных участков,

ст. 22 федерального закона РФ «О недрах» права и обязанности недропользователей,

ст. 40 федерального закона «О животном мире» - права и обязанности пользователей животным миром.

Наличие различных интересов в сфере природопользования у разных субъектов этих отношений предопределяет формирование объективных экономических противоречий, которые представляют собой объективные материальные противоречия, внутренне свойственные экономическим отношениям. Рассмотрим данные противоречия на примере лесных отношений. Выбор данных отношений в качестве объекта анализа предопределяется следующей совокупностью причин:

- высокая значимость лесов, как природных ресурсов, выполняющих не только экономические, но также социальные и экологические функции;

- множество различных видов деятельности, связанных с данным видом природных ресурсов: использование (лесозаготовки и использование других недревесных полезностей леса), охрана (охрана лесов от пожаров и незаконных вырубок), защита (защита лесов от вредителей и болезней) и воспроизводство лесов (лесовосста- 
новление);

- широкое распространение лесов на территории РФ;

- экономические особенности данных отношений, определяемые следующими факторами: лесные ресурсы - воспроизводимый природный ресурс, срок воспроизводства лесных ресурсов может превышать сто лет. Эти особенности требуют учета множества дополнительных факторов при принятии управленческих решений в области лесных ресурсов, что в значительной степени усложняют данный процесс;

- значимые текущие проблемы в области использования лесных ресурсов, что находит свое отражение в таких явлениях, как незаконные рубки, лесные пожары, постоянные корректировки Лесного Кодекса.

В области существующих лесных отношениях можно по мнению автора выделить следующие противоречия:

- в интересах хозяйствующих субъектов (бизнеса) и государства, как собственника ресурсов;

- в интересах федеральных и региональных органов лесного хозяйства;

- в интересах хозяйствующих субъектов (бизнеса) и населения (заинтересованность населения в постоянном бесплатном доступе в благоустроенные леса для сбора грибов, ягод и рекреации для себя и будущих поколений и применение коммерческими структурами низкозатратных технологий заготовки древесины и других продуктов леса, часто оказывающих негативное влияние на биогеоценоз);

- в условиях аренды лесов и изменяющейся рыночной конъюнктуры;

- в инструментах управления эффективностью процесса воспроизводства лесных ресурсов

Противоречие в интересах хозяйствующих субъектов и государства, как собственника ресурсов является одним из основных в лесном секторе. Различие экономических интересов государства и арендаторов лесных участков [2] выражается в следующем: государство, как собственник ресурса, заинтересованно в росте лесного дохода, размер которого определяется Постановлением Правительства РФ от 22.05.2007 N310 «О ставках платы за единицу объема лесных ресурсов и ставках платы за единицу площади лесного участка, находящегося в федеральной собственности», что будет повышать затраты лесозаготовителя и следователь- но уменьшать его прибыль. Эту ситуацию исследователи рассматривают как противоречие интересов лесной промышленности и лесного хозяйства, когда интересы лесопромышленников сфокусированы на снабжении их доступными и качественными древесными ресурсами в больших объемов по низким ценам, а представители лесного хозяйства заинтересованы в отпуске древесины по высоким ценам в объемах не превышающих размеры расчетной лесосеки. [9]. Рассматриваемое противоречие в настоящее время разрешается в пользу коммерческих структур, об этом свидетельствует существенное превышение расходов федерального бюджета на лесное хозяйство за 2019 год (42,3 млрд. руб.) над платой в федеральный бюджет за использование лесов в этот же период (34,4 млрд. руб.). Также об этом указывает сопоставление корневых цен древесины (ставок платы за древесину) в России и в зарубежных странах. Если корневая цена древесины за кубометр в странах Скандинавии, Прибалтики, в Соединённых Штатах Америки превышает 30 долларов США, то в России средняя ставки платы составляет около 2 долларов [6], что свидетельствует о заниженной стоимостной оценке лесных ресурсов.

Описанное выше противоречие также формирует целый комплекс конфликтов интересов, касающихся характеристик аренды участков лесного фонда. В число таких характеристик можно отнести:

- срок аренды (желание арендатора, как пользователя ресурсов, получить в аренду участок на длительный срок, интересы собственника ограничить срок аренды с учетом возможного изменения экономической конъюнктуры);

- объект за который производятся ресурсные платежи (конфликт между платежами за объем ресурсов согласно расчетной лесосеке (сколько разрешено заготавливать на участке леса) и фактическим объемом заготовки),

- осуществление лесохозяйственной деятельности арендатором участка лесного фонда (заинтересованность государства в качественном выполнении работ по охране, защите и воспроизводству лесов арендатором, и отсутствие экономических стимулов у арендатора в надлежащем выполнении этих работ).

Существующие условия аренды, часто формируют противоречие между низким уровнем дохода арендаторов лесных участков (особенно субъектов малого предпринимательства) и раз- 
мерами лесных платежей и стоимости работ по охране, защите и воспроизводству лесов [3].

В области лесных отношений также наблюдается противоречие, связанное с управлением процесса воспроизводства лесных ресурсов, заключающееся в несоответствии систем управления и в используемых инструментах управления на различных уровнях. Так в хозяйствующем субъекте, представленном вертикально-интегрированной лесной компанией, осуществляется управление всем расширенным циклом воспроизводства лесных ресурсов (лесохозяйственная деятельность - заготовка древесины -переработка древесины), с использованием комбинирования и интеграции производств. В то же время, на уровне государства в соответствии с Лесным кодексом управление ограничивается ведением только лесного хозяйства.

Данное противоречие наиболее концентрированно проявляется в лесном планирование при разработке лесных планов субъектов Российской Федерации, которые по аналогии с лесоустроительными проектами характеризуется применением ресурсного подхода при формировании результирующих показателей плана и отсутствием рыночной составляющей. Использование такого подхода, игнорирующего рыночные реалии, приводит как к формированию неоптимальных планов с позиции их эффективности, так и к частым случаям их не исполнения.

Проблема в согласовании интересов субъектов природопользования в обеспечении их сбалансированности может быть решена при использовании такой экономической категории как экономическая доступность природных ресурсов.

Доступность природных ресурсов устанавливается с учетом совокупности экономических и технологических факторов. Часто различают понятия технологической и экономической доступности. Под «технологической доступностью» природных ресурсов подразумевают физическую возможность вовлечения тех или иных природных ресурсов в хозяйственный оборот. Такие факторы, как большая глубина залегания природных ископаемых и низкий уровень концентрации полезных веществ в горной породе служат причиной их технологической недоступности, хотя развитие науки и технологии, может существенно изменить ситуацию, что мы видим на примере «сланцевой революции».

Возможность вовлечения природных ре- сурсов в хозяйственный оборот с позиций их экономической результативности отражает экономическая доступность. Применительно к предпринимателю данное условие выражается в получении нормативной прибыли при использовании природных ресурсов. Исходя из условий свободы экономического выбора, предприниматель не будет эксплуатировать те природные ресурсы, которые не смогут обеспечить ему получение определенного финансового результата и будут рассматриваться как экономически недоступные.

Экономическая доступность природных ресурсов формируется под воздействием множества экономических и не экономических факторов к которым можно отнести: их территориальное размещение, количественные и качественные характеристики, организационнотехнологический уровень добычи и переработки природных ресурсов, рыночную конъюнктуру и отраслевые особенности.

Первоочередную значимость при определения экономической доступности имеет ее критерий, на основании которого осуществляется классификация природных ресурсов по этому признаку. Существует множество подходов к его установлению и в практике научных исследований применялись такие варианты как положительная величина чистой текущей стоимости (NPV), положительные значения рентных оценок использования природных ресурсов, превышение их над экологическими затратами, превышение уровня рентабельности добычи ресурсов нормативного уровня, превышение текущих цен продуктов добычи над минимальным ценовым уровнем [5]. Применительно к сфере лесных отношений критерием экономической доступности древесины выступает равенство или превышение значения лесной ренты величины нормативной стоимости воспроизводства, охраны и защиты лесов. Величина нормативных затрат представляет собой экологические затраты, связанные с обеспечением неистощительного, непрерывного лесопользования в условиях аренды участков леса. Данный критерий имеет несколько модификаций в зависимости от того какой субъект лесных отношений производит оценку [8]. При этом под лесной рентой понимается остаточная стоимость (чистый доход), образуемая когда из полученного дохода от реализации продукции получат вознаграждение производственные факторы: капитал через нор- 
му прибыли, и труд через его оплату [11].

Использование экономической доступности природных ресурсов в практике природопользования позволит обеспечить сбалансированность интересов государства-собственника ресурсов и частного бизнеса. Интересы бизнеса (предпринимателей) защищает нормативная прибыль образуемая при эксплуатации и переработке природных ресурсов, которая учитывается при определении величины ренты. Интересы государства будут защищены, если платежи за природные ресурсы будут установлены с использованием рентного подхода предусматривающего изъятие сверхприбыли у природопользователей.

Применение показателей экономической доступности в практике планирования природопользования позволит существенно усилить его рыночную ориентацию. Так в сфере лесных отношений появляется возможность при использовании оценки экономической доступности лесных ресурсов разрабатывать лесные планы с учетом внедрения механизмов стимулирования использования лесных ресурсов, базирующихся на создании лесной инфраструктуры и формировании спроса на низкокачественную древесину. При этом одним из критериев оценки результативности лесного плана могут выступать объемы прироста экономически доступных лесных ресурсов в период его реализации. Экономическую доступность природных ресурсов следует рассматривать как инструмент, позволяющий системно принимать управленческие решения, нацеленные на расширение и повышение эффективности природопользования.

\section{Библиографический список}

1. Конституция Российской Федерации. Официальное издание.- М.: Юрид. лит., 2009. 64 с.

2. Большаков Н.М. Методологические подходы к воспроизводству лесных ресурсов в условиях их аренды / Н.М. Большаков, В.В. Жиделева, А. М. Попова, Е.А. Рауш // Экономика региона. - 2010. - № 2. - С. 117-129.

3. Морковина С.С. Экономическая модель интенсивного лесного хозяйства как основа равновесия интересов лесного бизнеса, государства, общества /С.С. Морковина // Труды Санкт-Петербургского научноисследовательского института лесного хозяйства. - 2016, - № 3 - С. $64-76$

4. Медяник Н.В. Природопользование как объект экономического стимулирования/ Н.В. Медяник - Вестник Челябинского государственного университета. - 2012. - № 8 (262). - Экономика. Вып. 36. - С. 70-78.

5. Новоселова И.Ю. Теоретико-методические основы оценки природно-ресурсного потенциала региона / И.Ю. Новоселова // Проблемный анализ и государственно-управленческое проектирование - 2011.№ 4.- С. 144-149.

6. Петров А.П. Экономические отношения в лесном хозяйстве: прошлое, настоящее и вызовы будущего/ A.П. Петров // Вопросы лесной науки. - 2019. - T 2 (1), - [Электронный ресурс] - Режим доступа. - URL: http://jsi.ru/2-1-2019-petrov/ (дата обращения 05.02.2020)

7. Стеблов А.Л. Экологическое право Российской Федерации и стран Европейского сообщества: Учебное пособие / А.Л. Стеблов, Я.И. Вайсман: Пермь. - 2010. - - [Электронный ресурс] - Режим доступа. - URL: http://be5.biz/pravo/e005/index.html (дата обращения 05.02.2020)

8. Третьяков, А.Г. Лесная рента и экономическая доступность лесных ресурсов: методологические аспекты /А.Г. Третьяков// Вестник Московского государственного университета леса - Лесной вестник. - 2015.№ 2 (т. 19). - С. 153-159.

9. Шутов И.В. Пружины механизма, разрушившего лесное хозяйство - [Электронный ресурс] - Режим доступа. - URL: http://www.forestforum.ru/viewtopic.php?t=17765 (дата обращения 05.02.2020)

10. Энгельс Ф. К жилищному вопросу / Маркс, К. и Энгельс Ф. Сочинения / К. Маркс, К. и Энгельс Ф., 2 изд. - М.: Государственное издательство политической литературы.- 1961- Т. 18.- С. 271

11. Zhang D., Pearse P.H. Forest Economics./ D. Zhang, P.H. Pearse - The University of British Columbia. - 2012. - 390 p. 